\title{
Occurrence of Diseases and Case of Clinical Diagnosis on Watermelon in South Korea, 2008-2012
}

*Corresponding author Tel : +82-63-290-6372 Fax: +82-63-290-6398 E-mail:nohjj@korea.kr
Received October 3, 2013

Revised January 3, 2014

Accepted January 26, 2014

\author{
Jaejong Noh ${ }^{1 *}$, Ju-Hee Kim², Jeong Hyeon Lim', Tae Bok Kim, Mun Ho Seong ${ }^{1}$, Gi \\ Tai Jung ${ }^{1}$, Jeong Man Kim ${ }^{3}$, Seong-Soo Cheong ${ }^{2}$, Nam Ki Oh${ }^{2}$ and Wang-Hyu Lee \\ 'Watermelon Experiment Station, Jeollabuk-do Agricultural Research and Extension Services, \\ Gochang 585-863, Korea \\ 2Jeollabuk-do Agricultural Research and Extension Services, Iksan 570-704, Korea \\ ${ }^{3}$ Seed Production \& Distribution Office, Jeollabuk-do Agricultural Research and Extension Services, \\ Iksan 570-390, Korea \\ ${ }^{4}$ Department of Agricultural Biology, Plant Medicinal Research Center, College of Agriculture \& Life \\ Science, Chonbuk National University, Jeonju 561-756, Korea
}

\begin{abstract}
The socio-network activities for regional governments, agricultural research institutes, developing agencies and policy makers of any countries are very crucial and important to take into account the root cause of current problems faced by farmers. The survey was conducted in South Korea during the period January, 2008 to August, 2012 in order to shed light on prevalence of different diseases on watermelon in different regions and to better understand farmers' knowledge and perceptions for following watemelon's growing procedures and practices. A total of 590 cases were reported on 573 watermelon growers with highest $87.1 \%$ in Jeonbuk, $4.7 \%$ in Jeonnam, and 8.2\% in other regions such as Gyeongbuk, Gyeongnam, Chungnam, Gwangju, Gyeonggi, Daegu, Gangwon, Changwon and Seoul. The maximum percentages of cases recorded were related to diseases and insect pest (38.6\%) followed by physiological disorder (29.7\%), cultural practices (18.8\%), soil and fertilizer $(9.0 \%)$, herbicide (2.9\%) and others (1.0\%). It was observed that the manifestation aspects of the diseases were changed due to increasing in proportion of 'in-facility' cultivation to 12,995 ha compared to 'open-field' cultivation (2,722 ha). The present survey revealed the necessity to reduce the damages incurred at watermelon farms as soon as possible through the breeding program to develop resistant cultivar, use of pathogen-free propagating plants, and efficient prevention of pathogen by regular monitoring of watermelon plants at farms.
\end{abstract}

Keywords : Farmers, Misconception, Monitoring, Network, Prevention

\section{Introduction}

The socio-network activities for regional governments, agricultural research institutes, developing agencies and policy makers of any countries are very crucial and important to take into account the root cause of current problems faced by farmers, find linkages, and points to the urgent needs and priorities to take necessary steps. These collective activities are recommended to be part of daily routine to amplify the chances of interception and relocation of resources to farmers in urgent need. The pool data collected with this kind of approach also

Research in Plant Disease

The Korean Society of Plant Pathology

pISSN 1598-2262, elSSN 2233-9191 helps to emphasize the necessity to deal with relevant problem faced by farmers with higher environmental impact.

Watermelon is one of the important cash crops in South Korea, the ninth largest watermelon producing country after China, India and United States. The production of watermelon was 608,986 tonnes with yield 38.75 tonnes/ha. The gross production value for watermelon in South Korea was $\$ 69,375,080$ with cultivation area of 15,717 ha (FAO, 2011). The cultivation area was peaked at 45,207 ha in 1995, but it has declined in each successive year (Park and Cho, 2013). Various fungi (Ali et al., 2012a) and viruses are major plant pathogens caused dramatic problems in watermelon (Bananej and Vahdat, 2008; Ali et al., 2012a; Ali et al., 2012b). Present commercial cultivars have been found to be susceptible to one or other kind of diseases. The priorities of breeders have been shifted from high yielding 
and high quality fruits to resistance to biotic and abiotic stresses for greenhouse culture. Disease control has been accomplished in South Korea, mainly, by grafting watermelon on bottle gourd or pumpkin, but, grafting is accompanied by higher labour costs and reduced fruit quality. During last some of years various problems related to diseases were reflected again during farmer's interaction at farm field. To study impact of damage incurred on crop by different types of diseases, a survey was planned under the supervision of Jeollabuk-do Agricultural Research and Extension Services (JBARES), Korea Institute of Planning and Evaluation for technology in Food, Agriculture, Forestry and Fisheries (IPET) and Rural Development Association (RDA).

The main objective of the survey was to shed light on prevalence of different diseases in watermelon crop in different regions and to better understand farmers' knowledge and perceptions for following watermelon's growing procedures and practices. The survey was conducted to study the occurrence of different diseases in watermelon crop at Jeonbuk province in South Korea during the period January, 2008 to August, 2012. The team members of this survey programme were researchers specialized in field of agronomy, plant pathology and plant breeding from Watermelon Experiment Station (JBARES), Gochang, Jeollabuk-do, South Korea. During the survey, data were purposed to be collected from different regions of provinces to pool the statistical data for the use of research activities so as to find the key solution for newly erupted diseases, and provide control measures to farmers for the diseases commonly occurring on watermelon farm.

I. This survey was carried out at five hundred-seventy three watermelon growers' fields in Jeonbuk, Jeonnam, Gyeong-

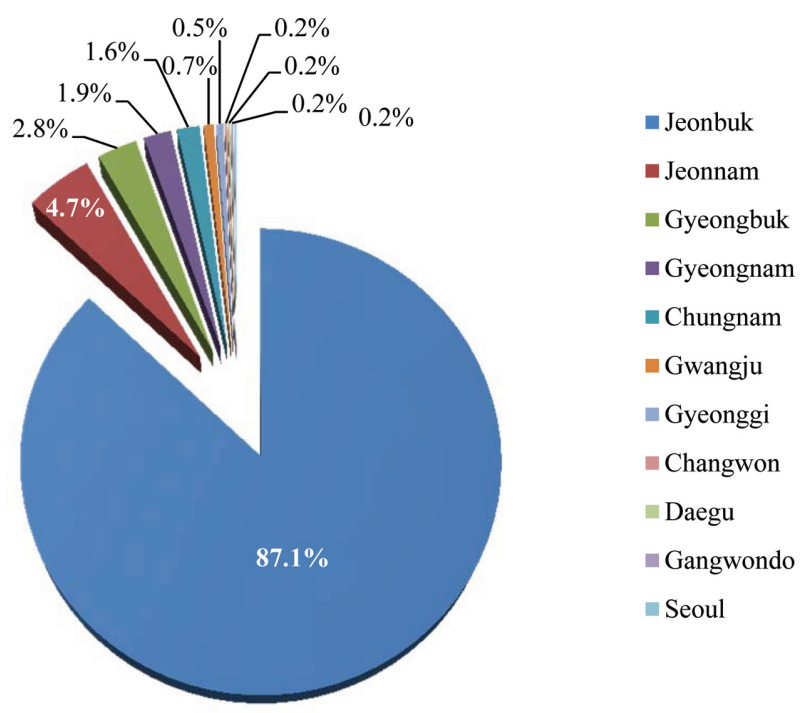

Fig. 1. Regional distribution of consulting in South Korea: Jeonbuk (87.1\%), Jeonnam (4.7\%), Gyeongbuk (2.8\%), Gyeongnam (1.9\%), Chungnam (1.6\%), Gwangju (0.7\%), Gyeonggi (0.5\%), Changwon (0.2\%), Daegu (0.2\%), Gangwon (0.2\%), and Seoul (0.2\%). buk, Gyeongnam, Chungnam, Gwangju, Gyeonggi, Daegu, Gangwon, Changwon and Seoul (Fig. 1). The consultation was distributed into six different categories as diseases and insect pests, physiological disorder, cultural practices, soil and fertilizer, herbicides and others.

II. The questionnaire regarding different problems of diseases were collected and answered on phones, by visiting farm or interviewing farmers visiting with infected samples.

The results provided here are of exploratory nature, and offer an outline to develop insights to prompt future analysis in this direction.

Domestic records of species in South Korea. A total of 590 cases were reported on 573 watermelon growers with highest $87.1 \%$ in Jeonbuk, $4.7 \%$ in Jeonnam, and $8.2 \%$ in other regions of Gyeongbuk, Gyeongnam, Chungnam, Gwangju, Gyeonggi, Daegu, Gangwon, Changwon and Seoul. Those observed farms showed damages caused by plant pathogens (bacteria, fungi and viruses) and other factors included harmful insects, cultural problems, physiological problems, soil fertilizer, herbicides, and others. Fluctuation of frequency of damaged cases based on each cause was observed from year to year. Number of viral diseases emerged cases were declined from 2008 to 2011, but increasing in 2012 that appeared contrary to physiological problems that increasing from 2008-2009 and continually decreased from 2009-2012 (Table 1). Total damaged cases were varied with the highest average frequency of diseases and insect pests (38.6\%) that included fungi (16.6\%), viruses (14.2\%) harmful insects $(6.3 \%)$, and bacteria $(1.5 \%)$, followed by physiological disorder (29.7\%), cultural practices (18.8\%), soil and fertilizer (9.0\%), herbicides (2.9\%) and others (1.0\%) (Fig. 2). A total of twenty nine domestic types of diseases are known as the causes of damages in watermelon. These includes nine types of viruses mainly, Cucumber green mottle mosaic virus (CGMMV), Kyuri green mottle mosaic virus (KGMMV), Zucchini green mottle mosaic virus (ZGMMV), Cucumber mosaic virus (CMV), Papaya ring spot virus (PRSV), Watermelon mosaic virus (WMV-1 and WMV-2), Melon necrotic spot virus, (MNSV), Zucchini yellow mosaic virus (ZYMV), two bacterial types (bacterial fruit blotch and bacterial leaf spot), eighteen fungi types (leaf blight, grey mold, leaf spot, scab, anthracnose, gummy stem rot, Fusarium wilt, fruit rot, root rot, Myrothecium leaf spot, blue mold, leaf spot, fruit and vine rot, downy mildew, damping off, Sclerotinia rot, fruit rot, and powdery mildew), and others like southern rootknot.

Prevalence of latest diseases. During last five years, production of watermelon was found severely affected by incidence of viral diseases (36.8\%). This has emerged as a major issue of consultation among watermelon growers (Fig. 3a). The questions on new strains of viruses including CGMMV, MNSV, PRSV and $\mathrm{BFB}$ and seed-borne contagious diseases were most frequently requested by the farmers in the regions of Jeonbuk. The dam- 
Table 1. Frequency of watermelon farms (\%) damaged by bacteria(Bac.), fungi(Fun.), viruses(Vir.), harmful insects(Ins.), cultural problems(Cul.), herbicides(Her.), physiological problems(Phy.), soil fertilizer(Soil), and others(Oth.) at several provinces in South Korea, 2008-2012

\begin{tabular}{|c|c|c|c|c|c|c|c|c|c|c|c|}
\hline Year & Area & $\begin{array}{l}\text { Bac. } \\
(\%)\end{array}$ & $\begin{array}{l}\text { Fun. } \\
(\%)\end{array}$ & $\begin{array}{l}\text { Vir. } \\
\text { (\%) }\end{array}$ & $\begin{array}{l}\text { Ins. } \\
\text { (\%) }\end{array}$ & $\begin{array}{l}\text { Cul. } \\
\text { (\%) }\end{array}$ & $\begin{array}{l}\text { Her. } \\
(\%)\end{array}$ & $\begin{array}{l}\text { Phy. } \\
(\%)\end{array}$ & $\begin{array}{l}\text { Soi. } \\
\text { (\%) }\end{array}$ & $\begin{array}{l}\text { Oth. } \\
\text { (\%) }\end{array}$ & $\begin{array}{l}\text { Tot. } \\
\text { (\%) }\end{array}$ \\
\hline \multirow[t]{12}{*}{2008} & Changwon* & & & & & & & & & & 0.0 \\
\hline & Chungnam* & & & & & & & & & & 0.0 \\
\hline & Daegu* & & & 0.6 & & & & & & & 0.6 \\
\hline & Gangwondo* & & & & & & & & & & 0.0 \\
\hline & Gwangju* & & & & & & & 0.6 & & & 0.6 \\
\hline & Gyeongbuk & & & 0.6 & & & & 0.6 & & & 1.2 \\
\hline & Gyeonggi* & & & & & 0.6 & & & & & 0.6 \\
\hline & Gyeongnam* & & & & & & & & & & 0.0 \\
\hline & Jeonbuk & 1.8 & 18.9 & 24.5 & 6.1 & 13.4 & 2.4 & 22.0 & 3.7 & 2.4 & 95.2 \\
\hline & Jeonnam & & 1.2 & & & 0.6 & & & & & 1.8 \\
\hline & Seoul & & & & & & & & & & 0.0 \\
\hline & Total & 1.8 & 20.1 & 25.7 & 6.1 & 14.6 & 2.4 & 23.2 & 3.7 & 2.4 & 100.0 \\
\hline \multirow[t]{12}{*}{2009} & Changwon* & & & & & & & 0.8 & & & 0.8 \\
\hline & Chungnam* & & & & & 0.8 & & & & & 0.8 \\
\hline & Daegu ${ }^{*}$ & & & & & & & & & & 0.0 \\
\hline & Gangwondo* & & & & & & & & & & 0.0 \\
\hline & Gwangju* & & & & & 0.8 & & & & & 0.8 \\
\hline & Gyeongbuk & & 0.8 & & & 0.8 & & 0.8 & & & 2.4 \\
\hline & Gyeonggi* & & & & & 0.8 & & & & & 0.8 \\
\hline & Gyeongnam & & & 0.8 & & & & 2.3 & & & 3.1 \\
\hline & Jeonbuk & & 13.6 & 13.0 & 7.5 & 21.3 & 3.8 & 25.1 & 2.3 & & 86.6 \\
\hline & Jeonnam & & & & 0.8 & 0.8 & & 2.3 & 0.8 & & 4.7 \\
\hline & Seoul ${ }^{*}$ & & & & & & & & & & 0.0 \\
\hline & Total & 0.0 & 14.4 & 13.8 & 8.3 & 25.3 & 3.8 & 31.3 & 3.1 & 0.0 & 100.0 \\
\hline \multirow[t]{12}{*}{2010} & Changwon* & & & & & & & & & & 0.0 \\
\hline & Chungnam & & & & & & & 0.9 & 0.9 & & 1.8 \\
\hline & Daegu* & & & & & & & & & & 0.0 \\
\hline & Gangwondo* & & & & & & & & & & 0.0 \\
\hline & Gwangju* & & & & & & & & & & 0.0 \\
\hline & Gyeongbuk & & 0.9 & & & & & 1.7 & & & 2.6 \\
\hline & Gyeonggi* & & & & & 0.9 & & & & & 0.9 \\
\hline & Gyeongnam & & & & & & & 1.7 & & & 1.7 \\
\hline & Jeonbuk & & 7.0 & 8.7 & 5.2 & 17.4 & 2.6 & 26.1 & 19.1 & & 86.1 \\
\hline & Jeonnam & & & & & 0.9 & 1.7 & 2.6 & 1.7 & & 6.9 \\
\hline & Seoul ${ }^{*}$ & & & & & & & & & & 0.0 \\
\hline & Total & 0.0 & 7.9 & 8.7 & 5.2 & 19.2 & 4.3 & 33.0 & 21.7 & 0.0 & 100.0 \\
\hline
\end{tabular}


Table 1. Continued

\begin{tabular}{|c|c|c|c|c|c|c|c|c|c|c|c|}
\hline Year & Area & $\begin{array}{l}\text { Bac. } \\
(\%)\end{array}$ & $\begin{array}{c}\text { Fun. } \\
(\%)\end{array}$ & $\begin{array}{l}\text { Vir. } \\
\text { (\%) }\end{array}$ & $\begin{array}{l}\text { Ins. } \\
(\%)\end{array}$ & $\begin{array}{l}\text { Cul. } \\
\text { (\%) }\end{array}$ & $\begin{array}{l}\text { Her. } \\
(\%)\end{array}$ & $\begin{array}{l}\text { Phy. } \\
\text { (\%) }\end{array}$ & $\begin{array}{l}\text { Soi. } \\
\text { (\%) }\end{array}$ & $\begin{array}{c}\text { Oth. } \\
\text { (\%) }\end{array}$ & $\begin{array}{l}\text { Tot. } \\
\text { (\%) }\end{array}$ \\
\hline \multirow[t]{12}{*}{2011} & Changwon* & & & & & & & & & & 0.0 \\
\hline & Chungnam & & 1.9 & & & & & 1.0 & & & 2.9 \\
\hline & Daegu* & & & & & & & & & & 0.0 \\
\hline & Gangwondo* & & & & & 1.0 & & & & & 1.0 \\
\hline & Gwangju* & & & & & 1.0 & & & & & 1.0 \\
\hline & Gyeongbuk & 1.9 & 1.0 & 1.0 & & & & 1.9 & & & 5.8 \\
\hline & Gyeonggi* & & & & & & & & & & 0.0 \\
\hline & Gyeongnam & & & & & 1.9 & & 1.9 & 1.0 & & 4.8 \\
\hline & Jeonbuk & 1.0 & 17.2 & 3.8 & 4.8 & 13.5 & & 26.8 & 8.7 & 1.9 & 77.7 \\
\hline & Jeonnam & & & & & 1.0 & & 3.8 & 1.0 & & 5.8 \\
\hline & Seoul ${ }^{*}$ & & & & & 1.0 & & & & & 1.0 \\
\hline & Total & 2.9 & 20.1 & 4.8 & 4.8 & 19.4 & 0.0 & 35.4 & 10.7 & 1.9 & 100.0 \\
\hline \multirow[t]{12}{*}{2012} & Changwon* & & & & & & & & & & 0.0 \\
\hline & Chungnam & 1.3 & & & & 1.3 & & 1.3 & & & 3.9 \\
\hline & Daegu* & & & & & & & & & & 0.0 \\
\hline & Gangwondo* & & & & & & & & & & 0.0 \\
\hline & Gwangju & & 1.3 & & & & & 1.3 & & & 2.6 \\
\hline & Gyeongbuk & 凶 & 1.3 & & & 1.3 & & & & & 2.6 \\
\hline & Gyeonggi* & & & & & & & & & & 0.0 \\
\hline & Gyeongnam* & & & & & & & & & & 0.0 \\
\hline & Jeonbuk & 2.7 & 18.5 & 11.8 & 6.6 & 11.8 & 4.0 & 22.4 & 7.9 & & 85.7 \\
\hline & Jeonnam & & & & & 1.3 & & 2.6 & 1.3 & & 5.2 \\
\hline & Seoul ${ }^{*}$ & & & & & & & & & & 0.0 \\
\hline & Total & 4.0 & 21.1 & 11.8 & 6.6 & 15.7 & 4.0 & 27.6 & 9.2 & 0.0 & 100.0 \\
\hline \multirow[t]{12}{*}{ Total } & Changwon* & & & & & & & 0.2 & & & 0.2 \\
\hline & Chungnam & 0.2 & 0.3 & & & 0.3 & & 0.5 & 0.2 & & 1.5 \\
\hline & Daegu* & & & 0.2 & & & & & & & 0.2 \\
\hline & Gangwondo* & & & & & 0.2 & & & & & 0.2 \\
\hline & Gwangju & & 0.2 & & & 0.3 & & 0.3 & & & 0.8 \\
\hline & Gyeongbuk & 0.3 & 0.7 & 0.3 & & 0.3 & & 1.0 & & & 2.6 \\
\hline & Gyeonggi & & & & & 0.5 & & & & & 0.5 \\
\hline & Gyeongnam & & & 0.2 & & 0.3 & & 1.2 & 0.2 & & 1.9 \\
\hline & Jeonbuk & 1.0 & 15.1 & 13.6 & 6.1 & 15.9 & 2.5 & 24.5 & 7.8 & 1.0 & 87.5 \\
\hline & Jeonnam & & 0.3 & & 0.2 & 0.8 & 0.3 & 2.0 & 0.8 & & 4.4 \\
\hline & Seoul ${ }^{*}$ & & & & & 0.2 & & & & & 0.2 \\
\hline & Total & 1.5 & 16.6 & 14.3 & 6.3 & 18.8 & 2.8 & 29.7 & 9.0 & 1.0 & 100.0 \\
\hline
\end{tabular}

*Number of survey farm $\leq 1$. 


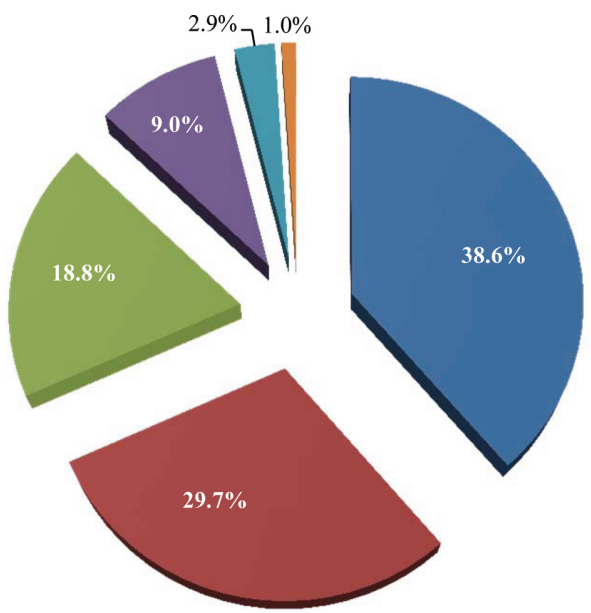

Fig. 2. Distribution of consulting categories.

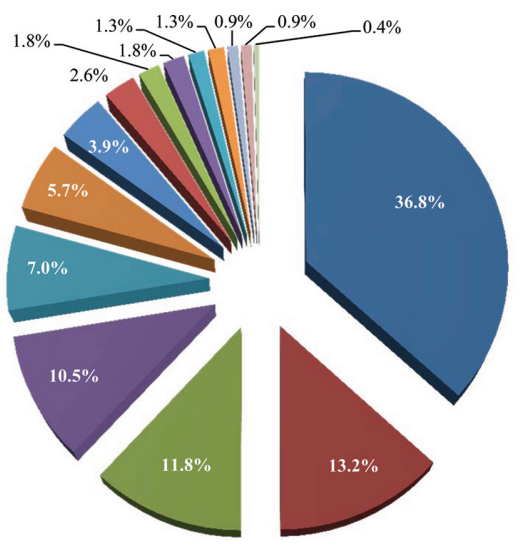

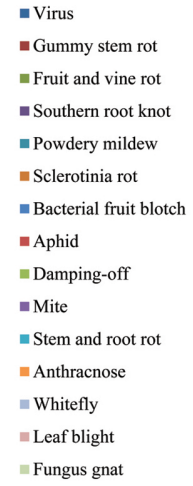

(a)

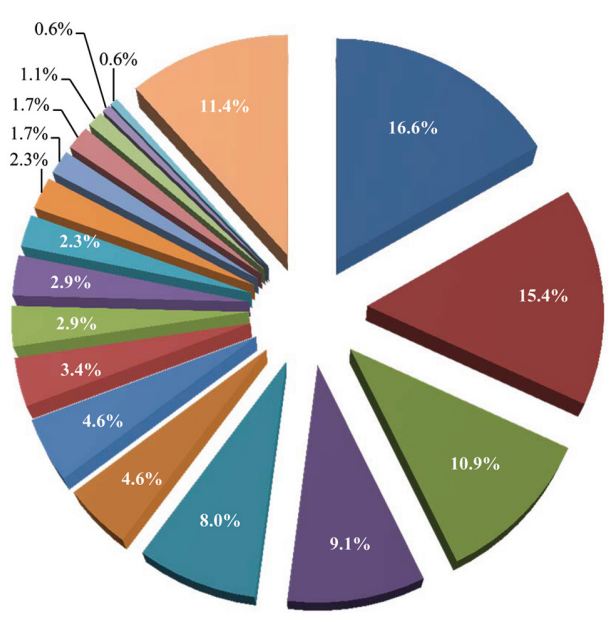

- Sudden wilt

- Chilling injury - Mg deficiency - Over growth - Chemical injury = Heat injury - Nutrient deficiency

- Poor anthesis

= Fruit cracking - Gas injury = Puffy fruit = Bad rooting $=$ Poor fruiting - Drought stress $\varpi$ Mechanical damage - Self-tipping Excess-moisture injury = Others

(b)
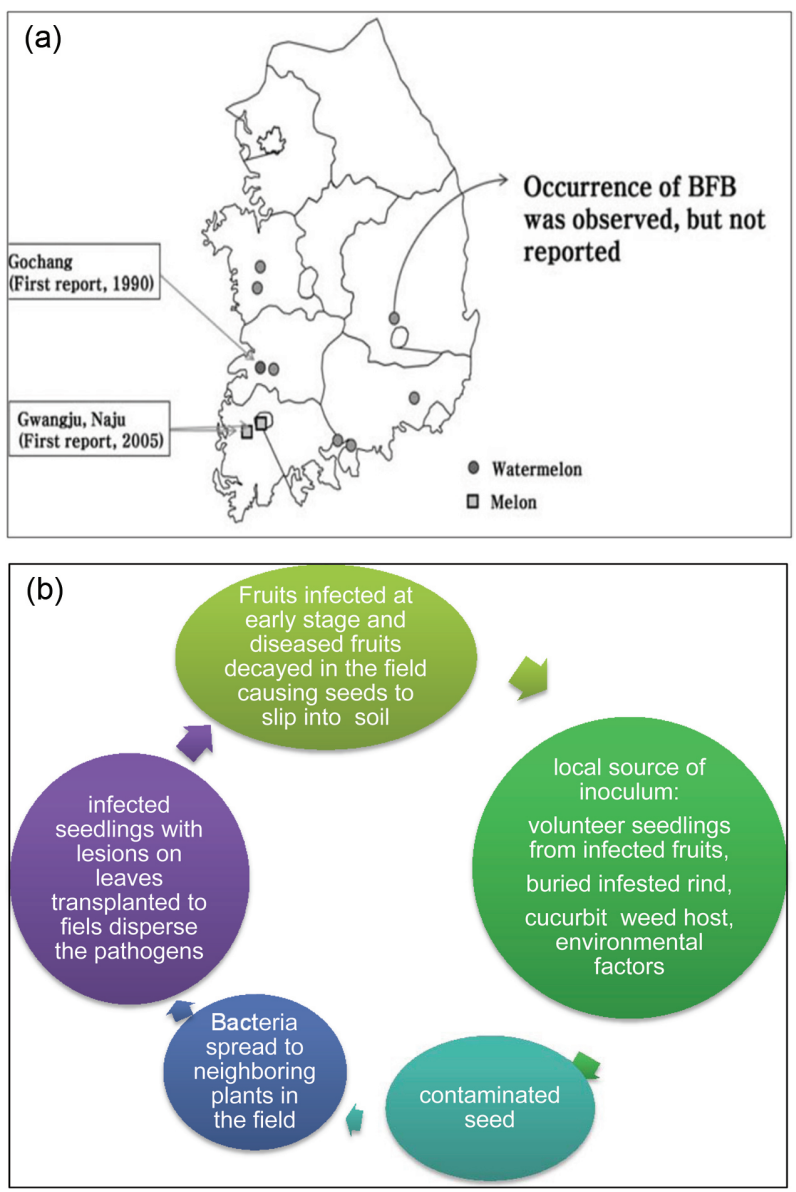

Fig. 4. Occurrence of bacterial fruit blotch (BFB) in South Korea (a) and disease cycle of BFB (b) (Lee, 2010).

eases were found to spread to neighbouring plants then to entire field/greenhouse very easily once erupt in single plant and left unnoticed by farmers. Based on the distribution pattern of diseases and insects, the incidence of gummy stem rot (13.2\%), fruit and vine rot (11.8\%), southern root-knot (10.5\%), powdery mildew (7.0\%), Sclerotinia rot (5.7\%), bacterial fruit blotch (3.9\%), aphid (2.6\%), damping-off (1.8\%), mite (1.8\%), stem and root rot $(1.3 \%)$, anthracnose $(1.3 \%)$, whitefly $(0.9 \%)$, leaf blight $(0.9 \%)$ and fungus gnat $(0.4 \%)$ were also commonly noticed on the farmers' fields. Among the physiological disorders (Fig. 3b), chilling injury (18.1\%), sudden wilt (17.5\%) and Mg deficiency (11.1\%) were recorded as more prominent besides chemical injury (7.6\%), over growth (7\%), heat injury (7\%), nutrient deficiency $(5.8 \%)$, poor anthesis $(3.5 \%)$, gas injury (2.9\%), excess moisture injury (2.9\%), fruit cracking $(2.3 \%)$, bad rooting (2.3\%), puffy fruiting (1.8\%), poor fruiting (1.8\%), mechanical damage (1.2\%), self-tipping (1.2\%), drought stress (1.2\%) and other types (4.7\%). These results were reflected in the outcome of the questionnaire survey conducted on the farms that showed that consultations and advices on issues related to diseases were most needed by farmers (Fig. 5). It has been observed that the manifestation aspects of the diseases were changed over the ages arising out of these diseases were observed as continually increasing in particularly from MNSV and PRSV since the first outbreak in the region of Naju, Jeonnam in 2001. These dis-

Fig. 3. Distribution of diseases (a) and insects and physiological disorder (b). 


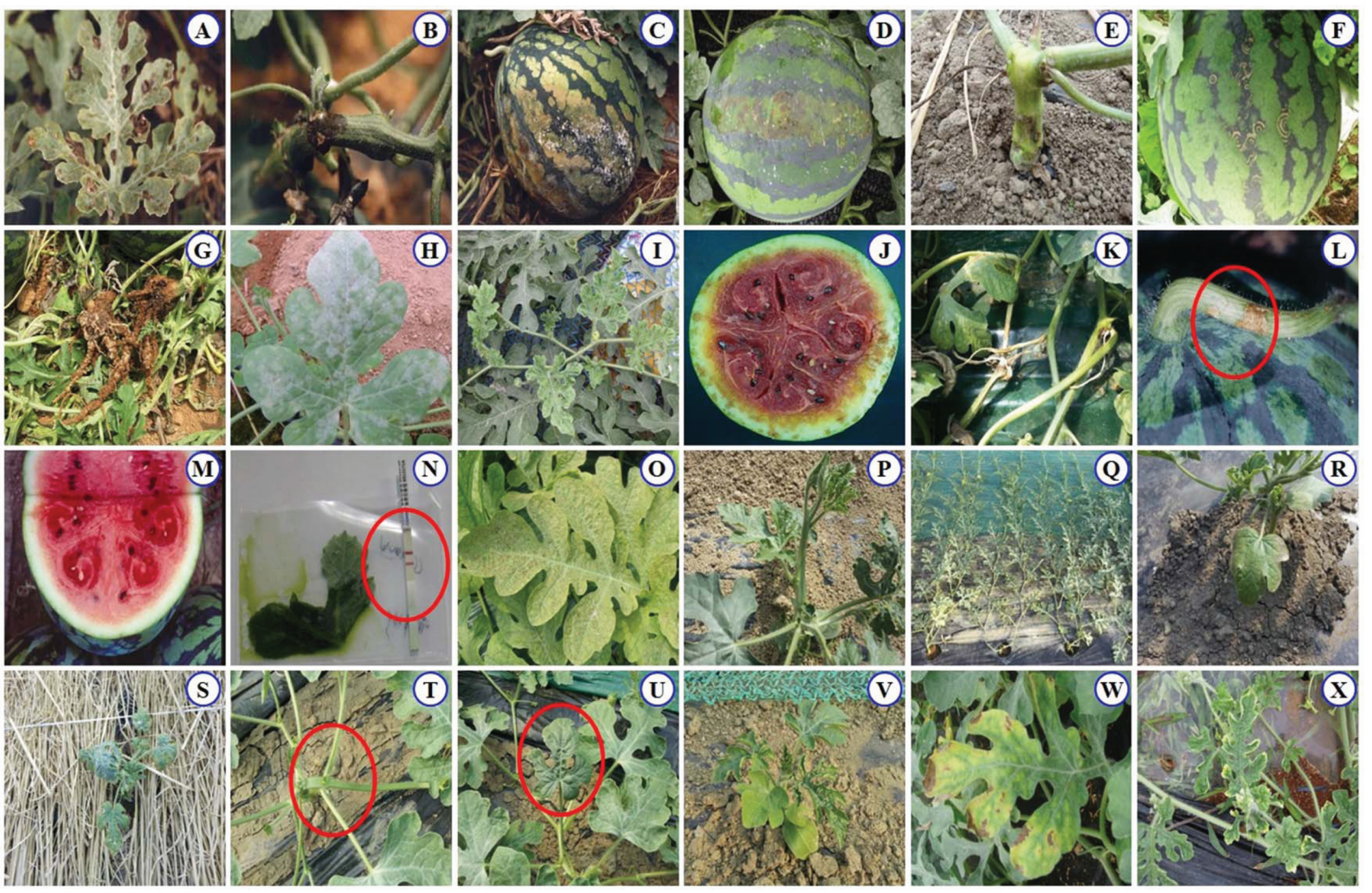

Fig. 5. The symptoms on watermelon at farmers' fields (from left to right above): anthracnose (A), gummy stem rot (B), fruit and vine rot (Phytophthora capsici, P.drechsleri, P. melonis) (C), bacterial fruit blotch (Acidovorax citrulli) (D), Fusarium wilt (Fusarium oxysporum f. sp. niveum) (E), Papaya ring spot virus (PRSV) (F), Southern root-knot (G), powdery mildew (Sphaerotheca fusca) (H), Watermelon mosaic virus (WMV) (I), Melon necrotic spot virus (MNSV) (J), Sclerotinia rot (Sclerotinia sclerotiorum) (K), Cucumber green mottle mosaic virus (CGMMV) on pedicel (L), fruit (M), and leaf (using Kit on farm) (N), Mg deficiency (injury misunderstood as disease) (O), abnormal shoot (P), poor growth in aqua culture (Q), chemical injury (R), chilling injury (S), abnormal shoot (T), stunt (U), moisture deficiency $(\mathbf{V})$, calcium deficiency $(\mathbf{W})$, and excess of calcium (injuries misunderstood as virus) (X).

years due to increasing in proportion of 'in-facility' cultivation to 12,995 ha, which was 4.8 times than 'open-field' cultivation $(2,722 \mathrm{ha})$. The pestilence those used to occur in open field earlier, now has been found to be manifested during relatively low temperature season in exceptionally, residential area of Iksan (April, 2012). The occurrence of powdery mildew in 'in-facility' cultivation was shown to be increasing due to repeated cultivation being practiced by the farmers. There were some farms where 'barn rot' was found depending on the status of how packaging is being managed.

Fusarium wilts (Fusarium oxysporum f. sp. niveum (E.F.Sm.) Synd. \& Hans) has been a major problem in the past and found wherever the crop has been crop in South Korea. It is not only emerged in South Korea, but also around the globe (Martyn and Mclaughlin, 1983; Kurt et al., 2008). In order to prevent breeding and extermination of Fusarium wilts, no severe damages aroused through adoption of grafting cultivation. During the survey some of the farms in the region of Namwon were noticed to be affected with Fusarium wilt, and that was mainly due to negligent management. A study also documented the existence and distribution of three races of Fusarium species in
South Korea. Race 0 at two locations; race 1 at eight locations; and race 2 in eleven fields (Kwon et al., 1998).

In recent years, it was found that bacterial diseases were on rise due to abnormally rainfalls and high fluctuating temperature, and constitutes serious constraints in watermelon crops. Bacterial fruit blotch (BFB) caused by Acidovorax species was first reported in Gochang in 1990 (Fig. 4a and b). This disease caused significant loss in production of watermelon during 2011-12. The recent trend in outbreaks of BFB were found primarily due to contaminated seeds procured from some seed companies based in South Korea, and secondary due to expansion of host range (watermelon, melon, cucumber, honeydew, squash, pumpkin, wild cucurbit, Capsicum spp., tomato crops), change in population structure, and difference in pathogenicity. Symptoms of BFB can be observed on the seedling transplants, mature leaves and fruit in watermelon (Fig. 5). Acidovorax sp. and $A$. avenae subsp. citrulli were isolated from the infected tissues of watermelon (unpublished data). Preventive measures were recommended to farmers as best strategies to be adopted for control of BFB. These were greenhouse sanitation, regular removing of weeds in and around greenhouse and open-field, 
and use of uncontaminated seeds and transplants. In case any kind of suspicious symptoms were observed by farmers, it was suggested to remove infected plants immediately and send samples for diagnosing to the nearby research institutes/station. The potentially infected plants need to be sprayed with copper-containing fungicides.

Misconception regarding certain diseases among farmers. During the field survey and questionnaire with farmers, it was observed that there were certain types of injuries commonly misunderstood as diseases due to similar look alike symptoms in watermelon crop. These were found mainly as magnesium deficiency, excess/or deficiency of calcium and others such as abnormal shoots and poor growth due to inadequate moisture, chemical injury, chilling injury, stunted growth and moisture deficiency (Fig. 5). Thus, farmers should be advised properly on the recognition of distinguishable causes of these symptoms and control measures to be taken should be applied after the advice from experts in the fields of crop pathology or physiology.

\section{Conclusion}

The exchange of information and know-how related to occurrence of diseases in watermelon crop and different kinds of problems faced by farmers has been kept and enforced by latest survey programme. Based on the survey's findings, it was suggested that management measures should be established to reduce the damages incurred in watermelon farms as soon as possible in order to develop and propagate efficient prevention of breeding of pathogen races by regular monitoring of farms, exterminate by continuously developing quick and accurate diagnostic technology, disclose the ecology of manifestation of watermelon diseases for affective control measures to be adopted, and build-up and strengthen socio-networking among research agencies, institutes, and farmers, and conduct regular training on timely basis to improve farmers' knowledge on diseases.

\section{Acknowledgement}

This work was supported by Jeollabuk-do Agricultural Research and Extension Services (JBARES), Korea Institute of Planning and Evaluation for technology in Food, Agriculture, Forestry and Fisheries (IPET) and Rural Development Association (RDA) grant.

\section{References}

Ali, A., Abdalla, O., Bruton, B., Fish, W., Sikora, E., Zhang, S. and Taylor, M. 2012a. Occurrence of viruses infecting watermelon, other cucurbits, and weeds in the parts of Southern United States. Online. Plant Health Progress doi.10.1094/PHP-2012-0824-01RS.

Ali, A., Mohammad, O. and Khattab, A. 2012b. Distribution of viruses infecting cucurbit crops and isolation of potential new viruslike sequences from weeds in Oklahoma. Plant Dis. 96: 243-248.

Bananej, K. and Vahdat, A. 2008. Identification, distribution and incidence of viruses in field-grown cucurbit crops of Iran. Phytopathol. Mediterr. 47: 247-257.

FAO 2011. www.FAOSTAT.

Kurt, S., Dervis, S., Soylu, E. M., Tok, F. M., Yetisir, H. and Solu, S. 2008. Pathogenic races and inoculum density of Fusarium oxysporum $\mathrm{f}$. sp. niveum in commercial watermelon fields in Southern Turkey. Phytoparasitica 36: 107-116.

Kwon,Y. S., Om, Y. H. and Kim, H. T. 1998. Identification and distribution of races of Fusarium oxysporum f.sp. niveum on watermelon in Korea. Cucurbit Genet. Coop. Report 21: 33-36.

Martyn, R. D. and Mclaughlin, R. J. 1983. Effects of inoculum concentration on the apparent resistance of watermelons to Fusarium oxysporum f. sp. niveum. Plant Dis. 67: 493-495.

Park, Y. H. and Cho, S. K. 2013. Watermelon production and breeding in South Korea. Israel J. Plant Sci. 60: 415-423.

Song, W. Y., Kim, H. M., So, I. Y. and Kang, Y. K. 1991. Pseudomonas pseudoalcaligenes subsp. citrulli: The causal agent of bacterial fruit blotch rot on watermelon. Korean J. Plant Pathol. 7: 177182. (In Korean) 